\title{
Comparison of the Myxobolus fauna of common barbel from Hungary and Iberian barbel from Portugal
}

\author{
K. Molnár ${ }^{1, *}$, E. Eszterbauer ${ }^{1}$, Sz. Marton ${ }^{1}$, Cs. Székely ${ }^{1}$, J. C. Eiras ${ }^{2}$ \\ ${ }^{1}$ Institute for Veterinary Medical Research, Centre for Agricultural Research, HAS, POB 18, 1581 Budapest, Hungary \\ ${ }^{2}$ Departamento de Biologia, e CIIMAR, Faculdade de Ciências, Universidade do Porto, Rua do Campo Alegre, s/n, \\ Edifício FC4, 4169-007 Porto, Portugal
}

\begin{abstract}
We compared Myxobolus infection of common barbel Barbus barbus from the Danube River in Hungary with that in Iberian barbel Luciobarbus bocagei from the Este River in Portugal. In Hungary, we recorded 5 known Myxobolus species (M. branchialis, M. caudatus, $M$. musculi, M. squamae, and M. tauricus) and described M. branchilateralis sp. n. In Portugal we recorded 6 Myxobolus species (M. branchialis, $M$. branchilateralis sp. n., M. cutanei, M. musculi, M. pfeifferi, and $M$. tauricus). Species found in the 2 habitats had similar spore morphology and only slight differences were observed in spore shape or measurements. All species showed a specific tissue tropism and had a definite site selection. $M$. branchialis was recorded from the lamellae of the gills, large plasmodia of $M$. branchilateralis sp. n. developed at both sides of hemibranchia, M. squamae infected the scales, plasmodia of $M$. caudatus infected the scales and the fins, and $M$. tauricus were found in the fins and pin bones. In the muscle, 3 species, M. musculi, M. pfeifferi and $M$. tauricus were found; however they were found in distinct locations. Plasmodia of M. musculi developed intracellularly in muscle cells, plasmodia of $M$. tauricus were found in the dense connective tissue of the pin bones, whereas $M$. pfeifferi formed plasmodia in the connective tissue of the intramuscular septa. This latter species was often found in the cartilaginous gill arch as well. Comparative morphological and phylogenetic studies, as well as 18S rDNA sequences, revealed differences between the Myxobolus fauna of the 2 barbel species originating from different geographic regions.
\end{abstract}

KEY WORDS: Myxozoa · Occurrence $\cdot$ Histology $\cdot$ Site selection $\cdot$ Phylogeny $\cdot$ Hungary $\cdot$ Portugal

\section{INTRODUCTION}

Barbels, members of the genus Barbus and related genera, are the most common cyprinid fishes inhabiting rivers of Eurasia and Africa. The number of barbel species in the Ponto-Caspian fauna region is less numerous. In the Danube River system, the Mediterranean barbel Barbus meridionalis Risso and the Petenyi's barbel $B$. petenyi Heckel are known along with the common barbel $B$. barbus (L.). In the rivers of the Iberian Peninsula, the occurrence of 5 species, Luciobarbus bocagei (Steindachner), L. comiso (Steindachner), L. microcephalus (Almaça), L. sclateri Günther, and Varicorhinus steindachteri (Almaça), has been recorded (Froese \& Pauly 2012). Of these, Iberian barbel $L$. bocagei is the most common species in the River Este. Hitherto, 29 Myxobolus species have been described from fishes of the genus Barbus and related genera (Luciobarbus, Carasobarbus, Hemibarbus, Labeobarbus, Spinibarbus) (Eiras et al. 2005). Only some of them are known from the barbel species inhabiting the rivers in Europe. Myxosporean fauna of the common barbel are relatively well studied and data are available from the late 
1800s onwards (Thélohan 1895, Keysselitz 1908, Schäperclaus 1954, Donec \& Shulman 1984).

From the type-host common barbel, 6 Myxobolus species, viz. M. branchialis (Markevich, 1932), $M$. cordis Keysselitz, 1908, M. musculi Keysselitz, 1908, M. pfeifferi Thélohan, 1895, M. squamae Keysselitz, 1908 and $M$. tisae Lom, 1969, have been described (Landsberg \& Lom 1991, Eiras et al. 2005). Donec \& Shulman (1984) reported that $M$. caudatus Gogebashvili, 1966 described from Barbus lacerta and $M$. tauricus Miroshnichenko, 1979 described from $B$. tauricus were also common parasites of common barbel. Alvarez-Pellitero \& Gonzalez-Lanza (1982, 1985) recorded $M$. tauricus, $M$. muelleri Bütschli, 1882, $M$. lobatus Dogiel, 1934 and described a new species, $M$. cutanei sp. n., in the Esla River, Spain.

This paper presents data from a collaborative investigation on Myxobolus infections of 2 barbel spp., Barbus barbus from the Danube River in Hungary and Luciobarbus bocagei from the Este River in Portugal. Besides morphology and histology, 18S rDNA sequence analysis and phylogeny were performed to compare the Myxobolus fauna of the 2 barbel species.

\section{MATERIALS AND METHODS}

Specimens of common barbel Barbus barbus (L.) were collected from the Danube River, Hungary, close to Budapest. Due to the methods, only smallsized, less than $14 \mathrm{~cm}$ long (altogether 36 specimens) and large-sized specimens over $40 \mathrm{~cm}$ (23 specimens) were obtained. Large-sized fish were purchased from commercial fishermen; the small-sized barbels were caught with a small-meshed seine. Iberian barbel Luciobarbus bocagei Steindachner were collected from the Este River, Portugal, north of Porto. Here, 22 specimens of 12 to $24 \mathrm{~cm}$ in length were caught using an electric fishing device.

Fish were transported to the laboratory alive in oxygenated plastic bags, kept in aerated aquaria and subjected to complete parasitological dissection within $3 \mathrm{~d}$. Fish were sedated using clove oil prior to euthanasia by severing the spinal cord at the base of the head. When mature plasmodia were found, some of the spores were examined on fresh preparations and others were collected into $1.5 \mathrm{ml}$ tubes and stored at $-20^{\circ} \mathrm{C}$ until further molecular use. The rest of the spores found were preserved in glycerinegelatine as slide preparations. Tissue samples from infected organs containing developing and mature plasmodia were fixed in Bouin's solution, embedded in paraffin wax, cut to 4-5 $\mu$ m sections, and stained with haematoxylin and eosin. The vitality of spores was checked by adding $0.4 \%$ urea to the myxospores. Myxospores of a given plasmodium were regarded as mature when at least $90 \%$ of the spores extruded polar filaments. The presence of the iodinophilous vacuole and the mucous envelope was examined on fresh spores under Nomarski differential interference on an Olympus $\mathrm{BH} 2$ microscope. The spores were photographed with an Olympus DP10 digital camera or recorded on videotapes, and digitized images were subsequently obtained. All measurements are given in micrometers $(\mu \mathrm{m})$. Measurements of fresh myxospores were taken with a calibrated eyepiece micrometer according to the guidelines of Lom \& Arthur (1989), or in a few exceptional cases, they were measured on the photomicrographs. Descriptions of all the species, except Мyхоbolus pfeifferi, are based on Myxobolus material collected from the Danube River.

\section{Molecular methods}

For DNA extraction, samples were centrifuged at $5000 \times g$ for $5 \mathrm{~min}$. Spore pellets were suspended in $500 \mu l$ lysis buffer $(100 \mathrm{mM} \mathrm{NaCl}, 10 \mathrm{mM}$ Tris, $10 \mathrm{mM}$ EDTA, $0.2 \%$ sodium dodecyl sulphate, and $0.4 \mathrm{mg}$ $\mathrm{ml}^{-1}$ Proteinase K) and incubated at $55^{\circ} \mathrm{C}$ for 3 to $4 \mathrm{~h}$. DNA was then purified using the Miniprep Express Matrix (BIO 101). Genomic DNA was amplified with the primer pair $18 \mathrm{e}\left(5^{\prime}-\mathrm{CTG}\right.$ GTT GAT TCT GCC AGT-3') (Hillis \& Dixon 1991) and 18r (5'-CTA CGG AAA CCT TGT TAC-3') (Whipps et al. 2003). The total volume of the PCR reactions was $50 \mu \mathrm{l}$, which contained approx. 10 to $50 \mathrm{ng}$ DNA, $1 \times$ Taq PCR reaction buffer (MBI Fermentas), $1.5 \mathrm{mM} \mathrm{MgCl}_{2}, 0.2 \mathrm{mM}$ dNTP mix (Sigma), $25 \mu \mathrm{M}$ of each primer and 2 units of Taq DNA Polymerase (MBI Fermentas). Amplification conditions were: $95^{\circ} \mathrm{C}$ for $50 \mathrm{~s}, 59^{\circ} \mathrm{C}$ for $50 \mathrm{~s}$, and $72^{\circ} \mathrm{C}$ for $80 \mathrm{~s}$ for 35 cycles, with a terminal extension at $72^{\circ} \mathrm{C}$ for $7 \mathrm{~min}$. When a weak band was detected on $1.0 \%$ agarose gel in TAE buffer, the amplicon was reamplified using nested PCR assay with inner primer pair SphF (5'-ACT CGT TGG TAA GGT AGT GGC T-3') and SphR (5'-GTT ACC ATT GTA GCG CGC GT-3') (Eszterbauer \& Székely 2004). Biometra T1 thermocycler was used for amplification. For PCR using SphF and SphR primers, the same condition was applied as for those with the 18e-18r primer pair. The PCR products were electrophoresed in $1.0 \%$ agarose gels (Sigma) in TAE buffer, and then purified with QIAquick Gel Extraction Kit (Qiagen). 
Purified PCR products were sequenced in both directions using the ABI BigDye Terminator v3.1 Cycle Sequencing Kit with an ABI 3100 Genetic Analyzer automated DNA sequencer (Applied Biosystems). The following primers were used for sequencing: amplification primers 18e and 18r, SphF and SphR, Myx4r and Act1f by Hallett \& Diamant (2001), and then MB5, MB3, MC5 and MC3 described by Eszterbauer (2004). For sequence assembling, the STADEN Sequence Analysis Package version 2001.0 (Staden 1996) was used. DNA sequence similarities were calculated with the Sequence Identity Matrix of the software BioEdit (Hall 1999).

\section{Phylogenetic analysis}

Nucleotide sequences were aligned with the software Multalin (Corpet 1988), available online. The alignment was corrected manually using the GeneDoc sequence alignment editor program. The dataset for the alignment was chosen on the basis of the results of basic local alignment search tool (BLAST) searches and morphological findings. Bayesian inference analysis was performed using MrBayes (Huelsenbeck \& Ronquist 2001) integrated in the software package TOPALi v2.5 (Milne et al. 2009). A general time reversible (GTR) model with gamma-shaped rate variations across sites (Invgamma) was found to be the best for the analysis, as determined by the 'modeltest' algorithm of the software. Two independent runs were conducted with 4 chains for 1 million generations. Phylogenetic trees were sampled every 100 generations. The first $25 \%$ of the samples were discarded from the cold chain (burninfrac $=0.25$ ), and a $50 \%$ majority-rule consensus tree was created, which was visualised by Treeview. Ceratomyxa shasta was chosen as the outgroup.

\section{RESULTS}

Six Myxobolus species, were found in common barbel Barbus barbus (Table 1). Of these, M. musculi infected the muscle of all examined large-sized barbels. However among small-sized barbels, only 3 specimens were found to be infected. In the gills, $M$. branchialis was the most common species. Small intralamellar plasmodia were found in most of the barbels examined. Besides $M$. branchialis infection, large plasmodia of an unknown Myxobolus species (described in this paper as $M$. branchilateralis sp. n.) were frequently found at the base of the gill filaments at both sides of the hemibranchia in the young-age fish group. Mature plasmodia of the species contained myxospores rather similar to the ones of $M$. branchialis. Attached to the pin bones, plasmodia of $M$. tauricus were found both in small- and large-sized barbel specimens. Small plasmodia of M. squamae could be found in the scales of both the young and old fish specimens. A sixth species, $M$. caudatus, was found in the scales and fins of smallsized barbels.

In the Iberian barbels Luciobarbus bocagei, 6 species were recorded (Table 1), identified on the basis of myxospore morphology and tissue tropism. No Myxobolus infection was previously known in this fish. M. branchialis, M. branchilateralis and M. musculi collected from Iberian barbel were found in the same locations as in common barbel. However, $M$.

Table 1. Prevalence of Myxobolus infection in barbels examined in Hungary (Danube, common barbel Barbus barbus) and Portugal (River Este, Iberian barbel Luciobarbus bocagei) in percent (\%). No. of infected fish/no. of examined fish in parentheses

\begin{tabular}{|c|c|c|c|c|}
\hline Myxobolus sp. & $\begin{array}{l}\text { Location } \\
\text { in host }\end{array}$ & $\begin{array}{l}\text { B. barbus } \\
>40 \mathrm{~cm}\end{array}$ & $\begin{array}{l}\text { B. barbus } \\
3-14 \mathrm{~cm}\end{array}$ & $\begin{array}{l}\text { L. bocagei } \\
12-25 \mathrm{~cm}\end{array}$ \\
\hline M. branchilateralis sp. $\mathrm{n}$. & Gills & - & $30(11 / 36)$ & $9(2 / 22)$ \\
\hline M. branchialis Markevitch, 1932 & Gill lamellae & $21(5 / 23)$ & $75(27 / 36)$ & $55(12 / 22)$ \\
\hline M. squamae Keysselitz, 1908 & Scales & $13(3 / 23)$ & $22(8 / 36)$ & - \\
\hline M. caudatus Gogebashvili, 1966 & Fins, scales & - & $6(2 / 36)$ & - \\
\hline M. cutanei Álvarez-Pellitero \& González-Lanza, 1985 & Fins, scales & - & - & $27(6 / 22)$ \\
\hline M. pfeifferi Thélohan, 1895 & $\begin{array}{l}\text { Muscles } \\
\text { Gill arch }\end{array}$ & $\begin{array}{l}- \\
-\end{array}$ & $\begin{array}{l}- \\
-\end{array}$ & $\begin{array}{l}23(5 / 22) \\
23(5 / 22)\end{array}$ \\
\hline M. musculi Keysselitz, 1908 & Muscles & $100(23 / 23)$ & $8(3 / 36)$ & $50(11 / 22)$ \\
\hline M. tauricus Miroshnichenko, 1979 & $\begin{array}{l}\text { Fins } \\
\text { Muscles }\end{array}$ & $13 \frac{-}{(3 / 23)}$ & $22-$ & $\begin{array}{c}36(8 / 22) \\
45(10 / 22)\end{array}$ \\
\hline
\end{tabular}




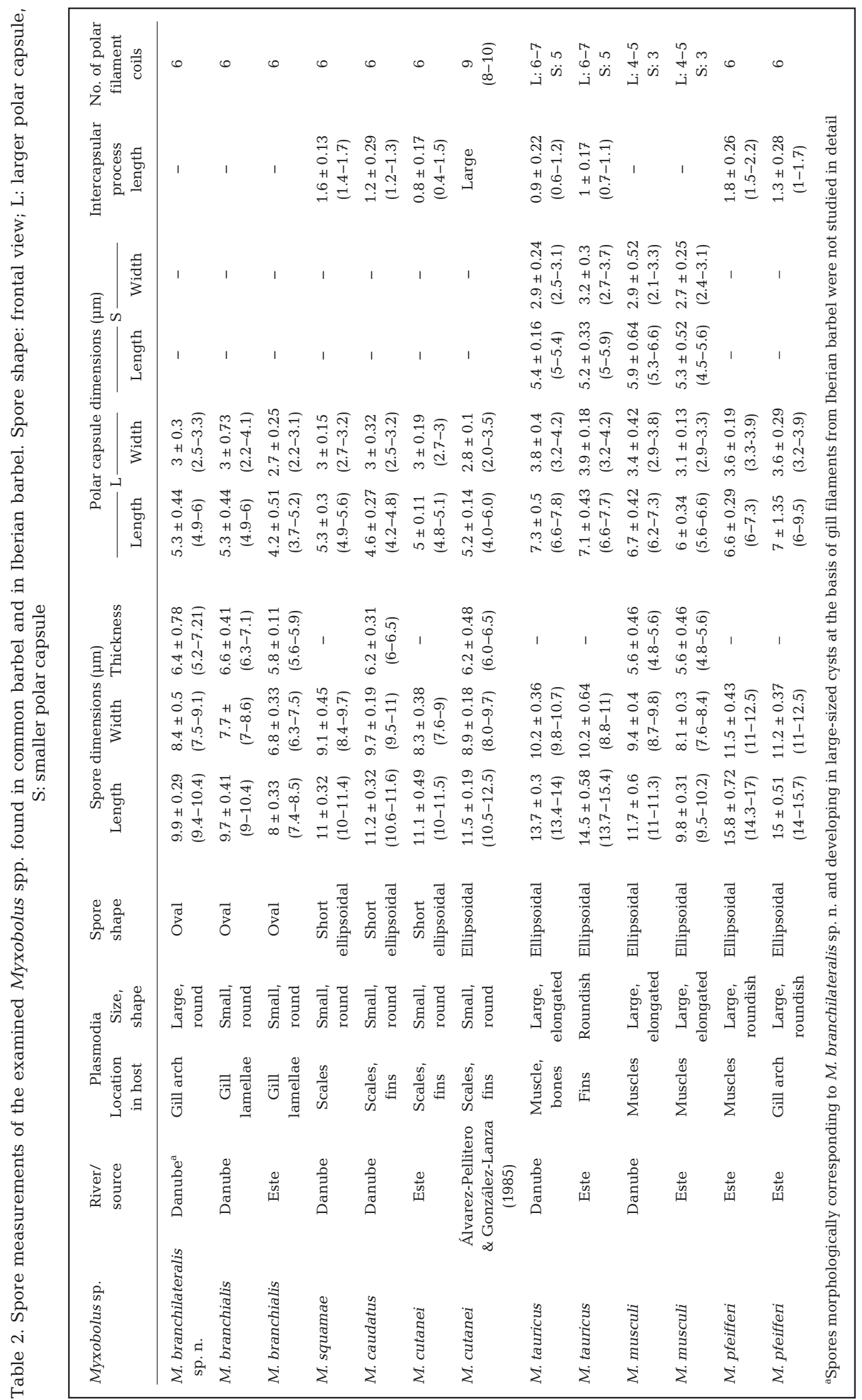


tauricus commonly appeared inside the fin rays as well. In the fins of Iberian barbel, a Myxobolus species was found that morphologically resembled $M$. caudatus; however 18S rDNA sequence data did not support the identity of the 2 isolates. Therefore the Myxobolus isolate from Iberian barbel was identified as $M$. cutanei, a species considered for a long time as a synonym of $M$. caudatus. In addition to parasites found in common barbel, Iberian barbel was found to be commonly infected with $M$. pfeifferi, a common parasite of barbels that has not been observed in Hungary to this date. This species was detected frequently in muscles, but large plasmodia were also commonly found in the gill arch under the base of the filaments. Heavy infections with Myxobolus spp. were frequently recorded in both fish species, but disease was not observed. Measurements of Мухоbolus spp. myxospores found in Hungary and Portugal are summarized in Table 2.

Of the 25 samples collected for molecular studies, the 18S rDNA of 19 samples was successfully sequenced. Although replicate samples were collected from Myxobolus branchialis, M. branchilateralis, M. caudatus, M. tauricus and M. musculi from the 2 barbel species, only $M$. caudatus ( $M$. cutanei), M. tauricus and M. musculi samples could be compared between the Hungarian and the Portuguese habitats. The remaining 6 samples had to be excluded from the analysis due to contamination and/or PCR inhibition issues. 18S rDNA sequence similarities of the examined samples are summarized in Table 3. The 18S rDNA of most of the samples were amplified with the nested PCR assay using primer pairs 18e-18r followed by SphF-SphR, and direct sequencing resulted in an approx. 1300 bp long DNA fragment (fragment length varied between 1315 and 1362 bp). Exceptions were the 3 examined samples of $M$. musculi, for which a single run PCR assay using the outer primer pair 18e-18r gave a sufficient amount of DNA for direct sequencing.

Bayesian inference analysis was performed on the basis of a $1694 \mathrm{bp}$ long final edited alignment that contained 42 DNA sequences (Fig. 1). The examined species clustered in 3 large branches. Мухоbolus pfeifferi, $M$. tauricus, $M$. cutanei, $M$. caudatus and M. squamae species grouped with the Myxobolus species that develop in the connective tissue of different organs. Both $M$. pfeifferi and M. caudatus are most closely related to hexactinomyxon-type actinospores, which might reflect the morphology of their alternate spore stage. $M$. branchialis and $M$. branchilateralis clustered with the gill-dwelling Myxobolus species possessing an elongated spore shape (like $M$. hungaricus and $M$. dujardini). $M$. musculi isolates grouped with the intramuscular Myxobolus species like M. cyprini and M. pseudodispar. Interestingly, $M$. stanlii and an unidentified Myxobolus species (Myxobolus sp. CMW-2004, AY591531) developing within a cyst in the muscle

Table 3. 18S rDNA sequence similarities of the examined Myxobolus species from common and Iberian barbel, on the basis of an 1313 bp long DNA alignment (in percent, \%). Samples underlined are from Portugal $(\mathrm{n}=8)$, the rest were collected in Hungary (n = 11). bra: $M$. branchialis; bri: $M$. branchilateralis; cau: M. caudatus; cut: M. cutanei; mus: M. musculi; sqa: M. squamae; pfe: M. pfeifferi; tau: M. tauricus

\begin{tabular}{|c|c|c|c|c|c|c|c|c|c|c|c|c|c|c|c|c|c|c|c|}
\hline Myxobolus sp. & bra1 & bra2 & bri1 & bri2 & bri3 & cau1 & cau2 & cut1 & cut2 & mus1 & $\underline{\text { mus2 }}$ & $\underline{\text { mus3 }}$ & mus4 & sqa1 & sqa2 & $\underline{p f e}$ & tau1 & $\underline{\operatorname{tau} 2}$ & $\underline{\text { tau3 }}$ \\
\hline M. branchialis 1 & - & & & & & & & & & & & & & & & & & & \\
\hline M. branchialis 2 & 100 & - & & & & & & & & & & & & & & & & & \\
\hline M. branchilateralis 1 & 93.6 & 93.6 & - & & & & & & & & & & & & & & & & \\
\hline M. branchilateralis 2 & 93.6 & 93.6 & 100 & - & & & & & & & & & & & & & & & \\
\hline M. branchilateralis 3 & 93.6 & 93.6 & 100 & 100 & - & & & & & & & & & & & & & & \\
\hline M. caudatus 1 & 76.6 & 76.6 & 76.3 & 76.3 & 76.3 & - & & & & & & & & & & & & & \\
\hline M. caudatus 2 & 76.5 & 76.5 & 76.3 & 76.3 & 76.3 & 99.9 & - & & & & & & & & & & & & \\
\hline M. cutanei 1 & 76.9 & 76.9 & 76.5 & 76.5 & 76.5 & 95.8 & 95.8 & - & & & & & & & & & & & \\
\hline$\overline{M . \text { cutanei } 2}$ & 77 & 77 & 76.6 & 76.6 & 76.6 & 95.9 & 96 & 99.8 & - & & & & & & & & & & \\
\hline$\overline{\text { M. musculi } 1 \text { AF380141 }}$ & 78.3 & 78.3 & 78.1 & 78.1 & 78.1 & 73.7 & 73.7 & 73.4 & 73.5 & - & & & & & & & & & \\
\hline M. musculi 2 & 78.2 & 78.2 & 78.2 & 78.2 & 78.2 & 74.1 & 74.1 & 73.7 & 73.8 & 97.6 & - & & & & & & & & \\
\hline$\overline{\text { M. musculi } 3}$ & 78.2 & 78.2 & 77.9 & 77.9 & 77.9 & 73.4 & 73.4 & 73.9 & 74 & 97.3 & 97.1 & - & & & & & & & \\
\hline M. musculi 4 & 78.2 & 78.2 & 77.9 & 77.9 & 77.9 & 73.2 & 73.2 & 73 & 73.1 & 97.4 & 97 & 97.2 & - & & & & & & \\
\hline$\overline{\text { M. squamae }}$ & 76.3 & 76.3 & 76.5 & 76.5 & 76.5 & 91.1 & 91.2 & 91.1 & 91.3 & 74.1 & 74.4 & 74.4 & 73.2 & - & & & & & \\
\hline M. squamae 2 & 76.3 & 76.3 & 76.5 & 76.5 & 76.5 & 91.1 & 91.2 & 91.1 & 91.3 & 74.1 & 74.4 & 74.4 & 73.2 & 100 & - & & & & \\
\hline M. pfeifferi & 77.1 & 77.1 & 76.8 & 76.8 & 76.8 & 90.8 & 90.9 & 90.9 & 90.9 & 74.5 & 74.6 & 74.3 & 73.8 & 89.2 & 89.2 & - & & & \\
\hline$\overline{\text { M. tauricus } 1}$ & 76.5 & 76.5 & 76.8 & 76.8 & 76.8 & 87.4 & 87.4 & 88.3 & 88.3 & 74.6 & 74.9 & 74.2 & 73.9 & 86.8 & 86.8 & 87.8 & - & & \\
\hline M. tauricus 2 & 76.8 & 76.8 & 77.1 & 77.1 & 77.1 & 87.4 & 87.5 & 88.1 & 88.1 & 74.5 & 74.9 & 74.2 & 73.7 & 86.6 & 86.6 & 86.8 & 96.9 & - & \\
\hline$\overline{M .}$ tauricus 3 & 76.8 & 76.8 & 77.1 & 77.1 & 77.1 & 87.4 & 87.5 & 88.1 & 88.1 & 74.5 & 74.9 & 74.2 & 73.7 & 86.6 & 86.6 & 86.8 & 96.9 & 100 & - \\
\hline
\end{tabular}




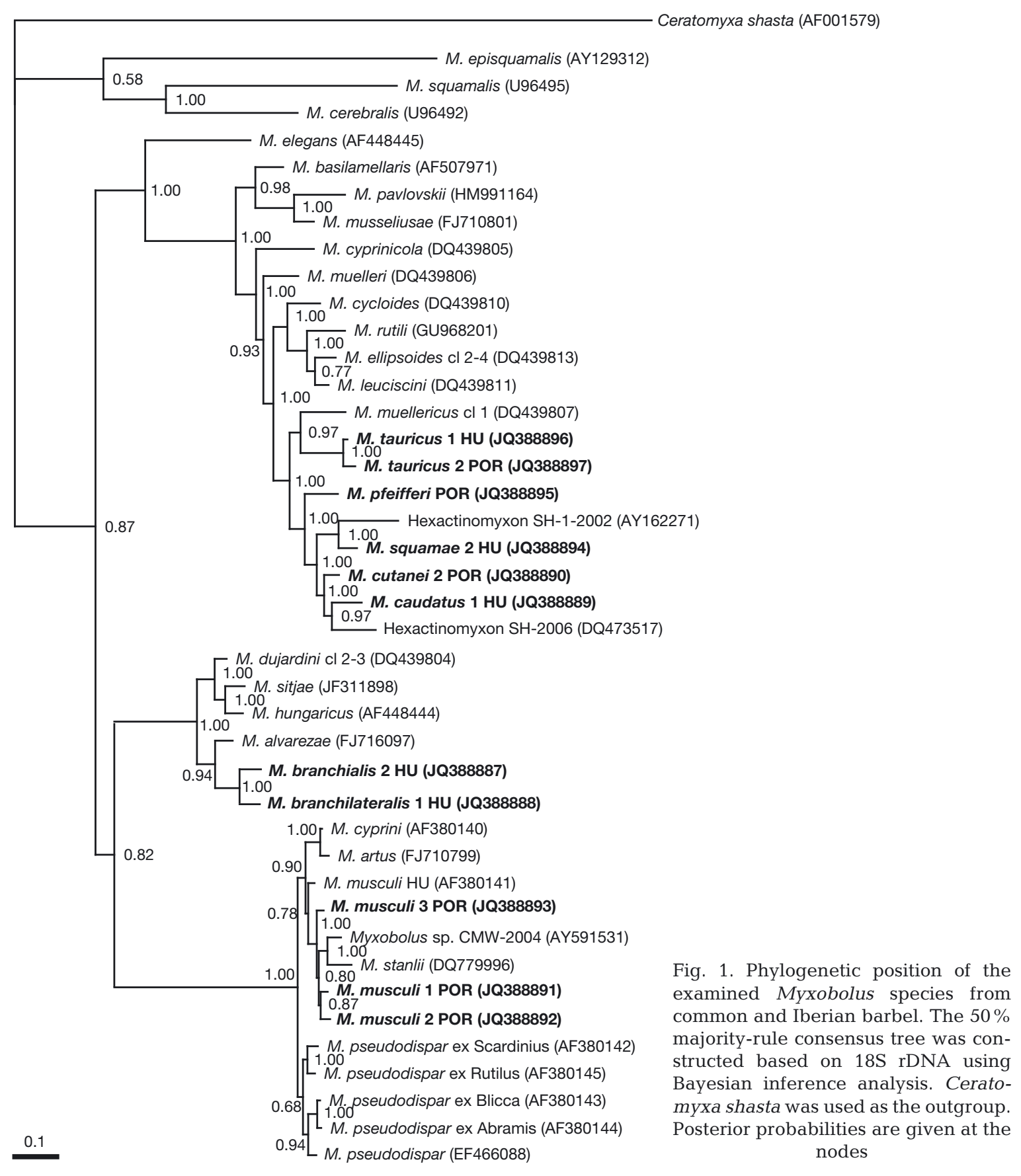

tissue of Northern pikeminnow Ptychocheilus oregonensis, placed within the group of $M$. musculi samples.

\section{Description of Myxobolus branchilateralis sp. $n$.}

Large, round plasmodia 1-2 $\mathrm{mm}$ in diameter were found at the basis of gill filaments in the 2 lateral sides of the gill hemibranchia. Infection with this parasite was found both in Hungary and Portugal. Only fingerlings and 1 yr old barbels were infected (Table 1 ).

Myxospores were oval, with tapered anterior ends in frontal view (Figs. 2a \& 3a), and lemon-shaped in sutural view with small sutural extensions at the anterior and posterior ends (Figs. 2a inset \& 3b). Spores were $9.7 \pm 0.49(9.4-10.4) \mu \mathrm{m}$ long $(\mathrm{N}=50)$, $8.2 \pm 0.68(7.5-9.1) \mu \mathrm{m}$ wide $(\mathrm{N}=50)$, and $6.4 \pm 0.78$ $(5.2-7.2) \mu \mathrm{m}$ thick $(\mathrm{N}=11)$. Polar capsules were pyriform, equal in size, slightly converging anteriorly, 5.6 

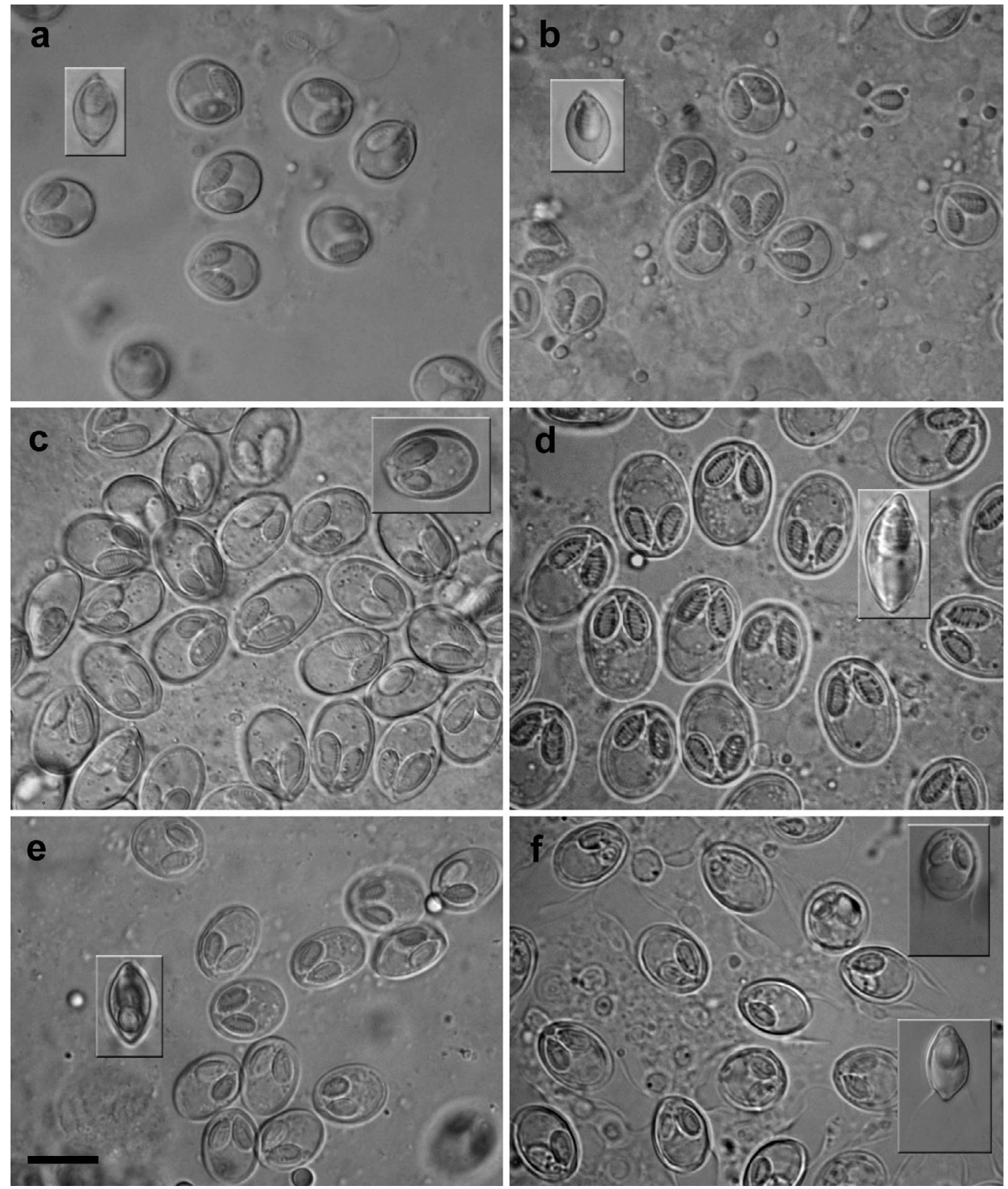

Fig. 2. Spores of Myxobolus spp. found in barbels shown in frontal and (inset) sutural views. (a) M. branchilateralis sp. n., (b) M. branchialis, (c) M. tauricus from Luciobarbus bocagei and (inset) Barbus barbus, (d) M. pfeifferi, (e) M. squamae, (f) M. cutanei from $L$. bocagei and (insets) M. caudatus from B. barbus in (upper) frontal and (lower) sutural views. Scale bar $=10 \mu \mathrm{m}$

$\pm 0.48(5.3-6.8) \mu \mathrm{m}$ long $(\mathrm{N}=50)$ and $3 \pm 0.37$ $(2.5-3.3) \mu \mathrm{m}$ wide $(\mathrm{N}=50)$. Six filament coils arranged oblique to the capsule length were wound densely in the polar capsule. No intercapsular appendix was found in the spores. Sutural protrusion formed a relatively thin circular rim around the spore emerging about 0.4 to $0.7 \mu \mathrm{m}$ over the surface of the spore. The rim of the suture in sutural view emerged from the spore surface 0.5 to $0.8 \mu \mathrm{m}$ at the anterior and the posterior ends of the spore. Sutural edge markings were not seen. The single binucleated sporoplasm had no iodinophilous vacuole. Around some spores, a thin mucous envelope was found. Spores from plasmodia found in Iberian barbels were not studied in detail.

Type host: common barbel Barbus barbus (L.) (Cyprinidae).

Additional host: Iberian barbel Luciobarbus bocagei (Steindachner) (Cyprinidae).

Type locality: Danube River, Hungary. 
a
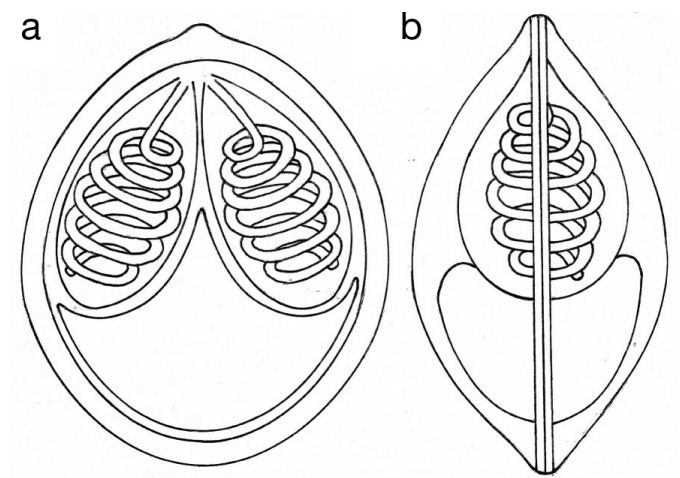

C

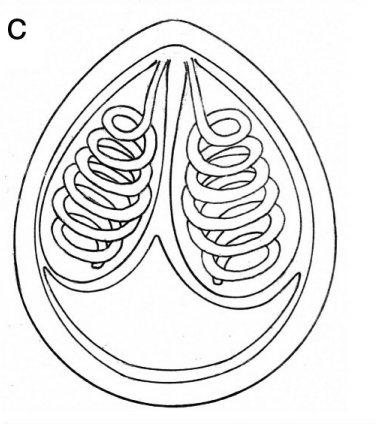

$\mathrm{d}$

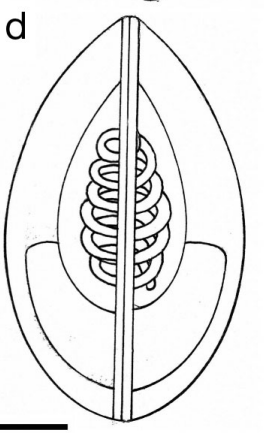

Fig. 3. Schematic drawings of spores of Myxobolus spp. infecting barbels. (a) $M$. branchilateralis sp. n. in frontal view, (b) M. branchilateralis sp. $\mathrm{n}$. in sutural view, (c) M. branchialis in frontal view, (d) M. branchialis sp. n. in sutural view. Scale bar $=10 \mu \mathrm{m}$

Site of tissue development: Basal part of gill filaments close to the gill arch at the 2 lateral sides of hemibranchia.

Type material: Syntype spores in glycerine jelly were deposited in the parasitological collection of the Zoological Department, Hungarian Natural History Museum, Budapest, Coll. No. HNHM-18217. The 18S rDNA sequence of Myxobolus branchilateralis sp. n. was deposited in GenBank under the accession number JQ388888.

Prevalence of infection: $30 \%$ in young common barbel and $9 \%$ in Iberian barbel.

Etimology: The species is named after the specific location of plasmodia in hemibranchia.

Molecular data: 18S rDNA sequences of 3 parallel samples of Myxobolus branchilateralis (GenBank Accession No. JQ388888) collected from the gill filaments of 3 common barbel specimens were $100 \%$ identical. The highest similarity $(93.6 \%)$ was to $M$. branchialis species, a frequent parasite in the barbels' gill. Genetic similarities to some other relevant Myxobolus species were $90.5 \%$ to $M$. hungaricus, $90.1 \%$ to $M$. dujardini and $79.8 \%$ to M. elegans.

Histology: Large, roundish plasmodia developed at the base of the gill filaments were attached to the surface of the gill arches (Fig. 4). In a characteristic way, the plasmodia were located only at the 2 sides of the gill hemibranchia. Also, we observed the large plasmodia deformed the filaments, and no gill filaments were seen.

Remarks: The shape and size of the myxospores of the species highly resemble $M$. branchialis, a common parasite of the gill lamellae, and in most cases a concomitant infection was recorded. The size and shape of the spores of the 2 species is very similar, but the anterior end of the Myxobolus branchilateralis spore is somewhat less tapered. On the basis of $18 \mathrm{~S}$ rDNA, $M$. branchilateralis sp. n. remarkably differs from $M$. branchialis. Spores from the Iberian barbel morphologically correspond to $M$. branchilateralis sp. n., and develop in large basilamellar plasmodia at the 2 sides of the gill hemibranchia. However their myxospore morphology was not studied in detail.

\section{Re-description of Myxobolus branchialis (Markevich, 1932)}

Small round plasmodia 60 to $120 \mu \mathrm{m}$ in diameter were found in the capillary network of the gill lamellae. The species was frequently found in large- and small-sized barbels, and both in common barbel and Iberian barbel.

Myxospores were pyriform, with tapered anterior ends in frontal view (Figs. 2b \& 3c) and citric shape in sutural view with small sutural extensions at the anterior ends (Fig. 2b inset \& 3d). Spores were $9.7 \pm 0.48$ (9.0-10.4) $\mu \mathrm{m}$ long $(\mathrm{N}=50), 7.6 \pm 0.5(7.0-8.6) \mu \mathrm{m}$ wide $(\mathrm{N}=50)$, and $6.6 \pm 0.41(6.3-7.1) \mu \mathrm{m}$ thick $(\mathrm{N}=11)$. Polar capsules were pyriform, equal in size, slightly converging anteriorly, and $5.3 \pm 0.49(4.9-6.0) \mu \mathrm{m}$ long $(\mathrm{N}=50)$ by $3 \pm 0.75(2.2-4.1) \mu \mathrm{m}$ wide $(\mathrm{N}=50)$. Six filament coils arranged oblique to the capsule length were wound densely in the polar capsule. No intercapsular appendix was found in the spores. Sutural protrusion formed a relatively thin circular rim around the spore emerging about 0.3 to $0.7 \mu \mathrm{m}$ over the surface of the spore. The rim of the suture emerged from the spore surface $0.5 \mu \mathrm{m}$ at the anterior and $0.7 \mu \mathrm{m}$ at the posterior end of the spore. Sutural edge markings were not seen. The single binucleated sporoplasm had no iodinophilous vacuole in the spore. A thin mucous envelope was found around some spores.

Hosts: Common barbel Barbus barbus (L.) (Cyprinidae) and Iberian barbel Luciobarbus bocagei (Steindachner), (Cyprinidae).

Locality: Danube River, Hungary and Este River, Portugal. 

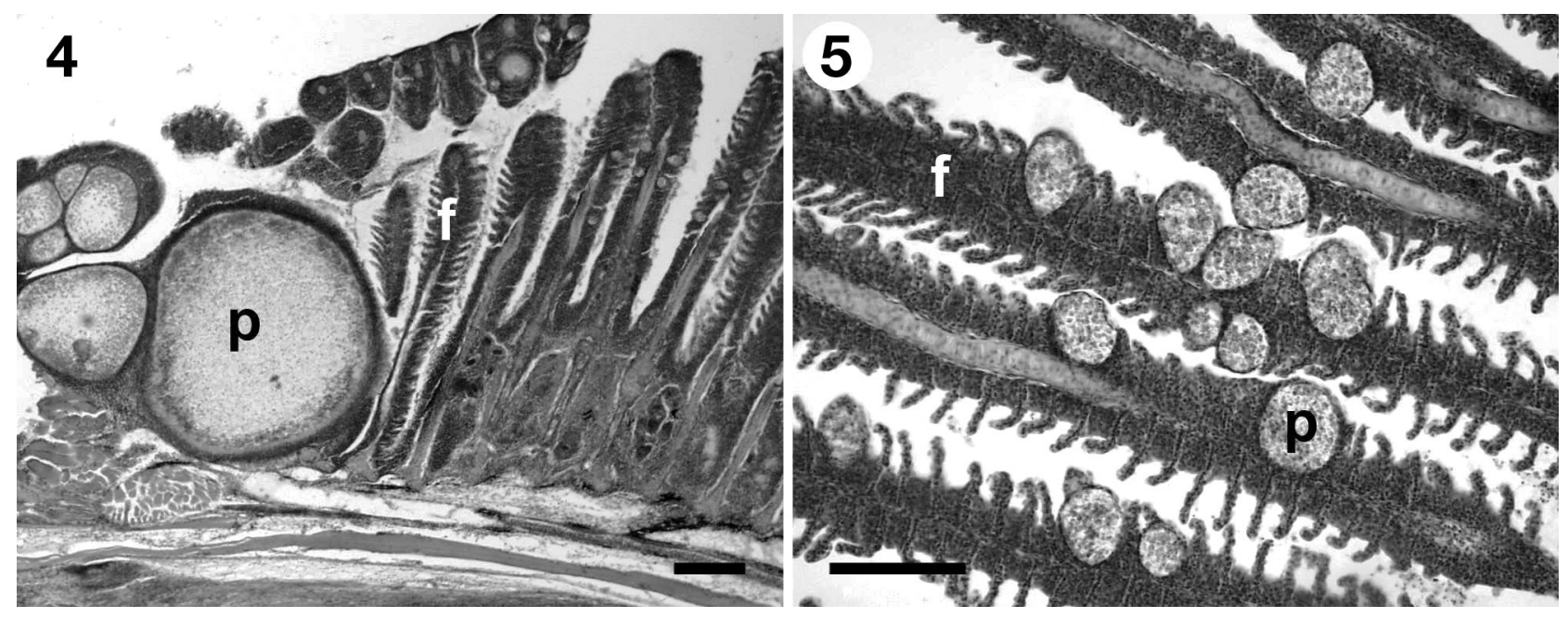

Figs. 4 \& 5. Myxobolus spp. infecting barbel. Fig. 4. Large plasmodia (p) of $M$. branchilateralis sp. n. at the lateral edge of the hemibranchia compressing gill filaments (f). Histological section. Haematoxylin and eosin (H \& E). Fig. 5. Plasmodia (p) of M. branchialis in the gill lamellae of the gill filaments (f). Histological section. H \& E. Scale $\overline{\text { bars }}=200 \mu \mathrm{m}$

Site of tissue development: Capillary network of gill lamellae.

Type material: Voucher spores in glycerine jelly were deposited in the parasitological collection of the Zoological Department, Hungarian Natural History Museum, Budapest, Coll. No. HNHM-18218. The 18S rDNA sequence of Myxobolus branchialis was deposited in GenBank under the accession number JQ388887.

Prevalence of infection: $75 \%$ in young and $21 \%$ in old common barbels, and $55 \%$ in Iberian barbel.

Molecular data: Two 18S rDNA sequences of Myxobolus branchialis samples from common barbel showed $100 \%$ identity. Of the other species having 18S rDNA sequence identified, $M$. branchilateralis showed the highest similarity $(93.6 \%)$. Morphologically similar species such as $M$. hungaricus, $M$. dujardini and M. elegans were 90.9, 90.1 and 79.1\% similar to $M$. branchialis, respectively.

Histology: Small, roundish plasmodia developed in the capillary network of the gill lamellae (Fig. 5).

Remarks: The shape and size of the spores of this species highly resembles Myxobolus branchilateralis sp. n., in its $18 \mathrm{~S} \mathrm{rDNA}$; however, $M$. branchialis notably differs from the latter species (Fig. 1).

\section{Re-description of Myxobolus tauricus Miroshnichenko, 1979}

The species was found both in common barbel Barbus barbus and in Iberian barbel Luciobarbus bocagei. Plasmodia in common barbel from the Danube
River were ellipsoid to oval and were found on the cartilaginous pin bones inside the dense collagenous connective tissue which surrounded and formed these bones (Fig. 6). Plasmodia in Iberian barbels were found both in collagenous elements among muscle cells and in the fin rays (Figs. $7 \& 8$ ).

The myxospores of the species possess remarkable characteristics. In frontal view, they are relatively large, having an ellipsoidal shape, but at the anterior end, they bear a distinct extension directed parallel to the longitudinal axis (Figs. 2c \& 10a). In sutural view, spores are asymmetrical, having a convex and a flattened side (Figs. 2c \& 10b).

Spores were $14 \pm 0.58(13.4-15.4) \mu \mathrm{m}$ long, $10.2 \pm$ 0.64 (8.8-11.0) $\mu \mathrm{m}$ wide, $8.4 \pm 0.14(8.2-8.6) \mu \mathrm{m}$ thick. Two polar capsules, which were elongated and pyriform, differed in size. The larger capsule was $7.2 \pm$ $0.53(6.6-7.8) \mu \mathrm{m}$ long, $3.9 \pm 0.40(3.2-4.2) \mu \mathrm{m}$ wide, while the smaller capsule was $5.3 \pm 0.43(5-5.9) \mu \mathrm{m}$ long and $3.1 \pm 0.35(2.5-3.7) \mu \mathrm{m}$ wide. Polar filaments were coiled with 6 to 7 turns in the larger polar capsule and with 5 turns in the smaller one. They were positioned perpendicularly or obliquely to the longitudinal axis of the capsule. Spores had a strong but indistinct triangular intercapsular appendix of $1.5 \pm$ $0.27(1.0-1.6) \mu \mathrm{m}$ at the anterior end. Sporoplasm nuclei were indiscernible. A large iodinophilous vacuole was found in the sporoplasm.

Hosts: Common barbel Barbus barbus (L.) and Iberian barbel Luciobarbus bocagei (Steindachner) (Cyprinidae).

Localities: Danube River, Hungary and Este River, Portugal. 

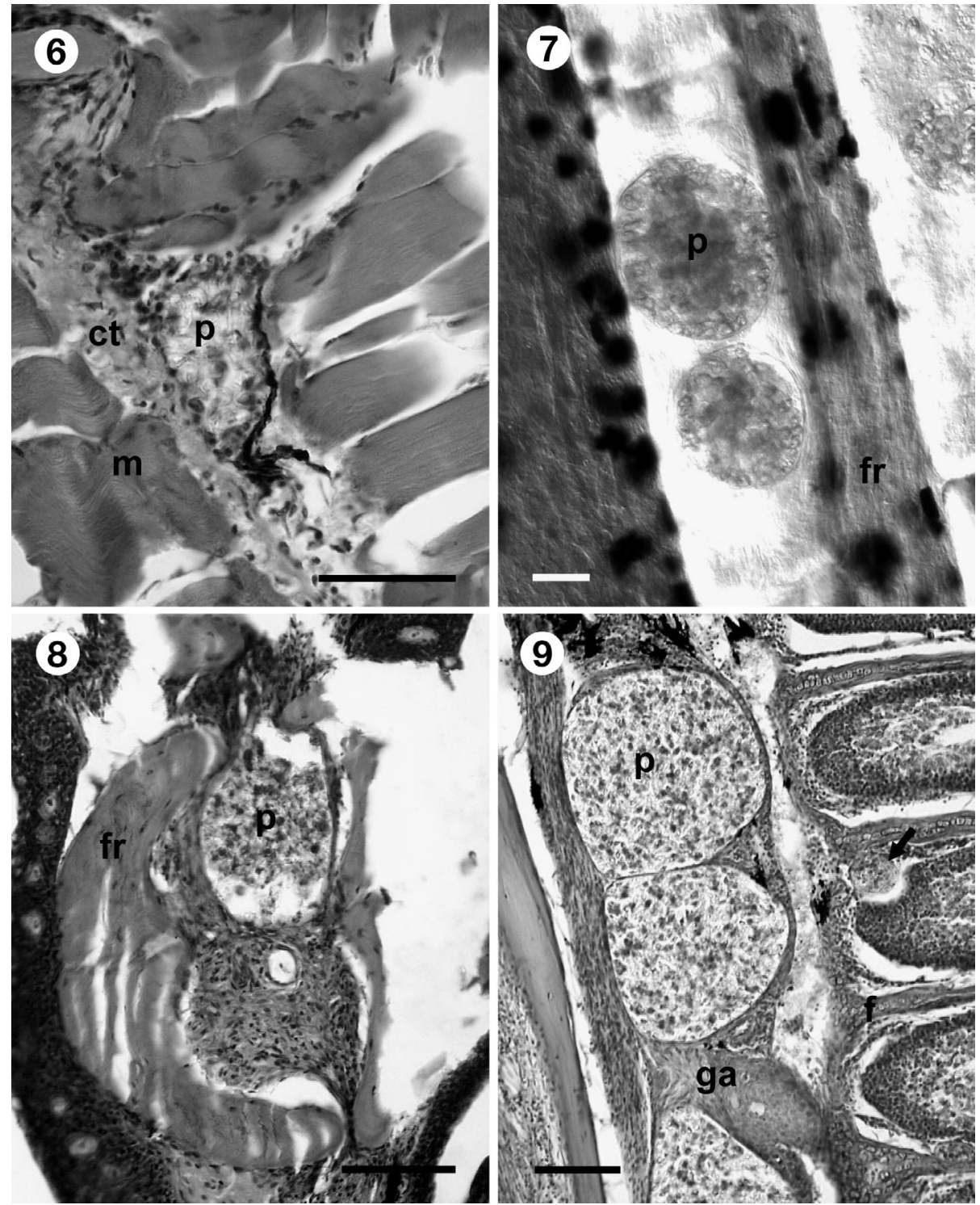

Figs. 6 to 9. Plasmodia (p) of Myxobolus spp. infecting barbel. Fig. 6. M. tauricus from Barbus barbus in the muscle (m) attaching to the collagenous connective tissue (ct) covering pin bones. Histological section. H \& E. Fig. 7. M. tauricus from Luciobarbus bocagei inside the lumen of the cartilaginous finrays (fr). Fresh mounts. Fig. 8. M. tauricus from $L$. bocagei in the lumen of a cartilaginous finray (fr). Histological section. H \& E. Fig. 9. M. pfeifferi in the cartilaginous gill arch (ga). (Arrow) Plasmodia may also be located at the basis of the gill filaments (f). Histological section. H \& E. Scale bar $=100 \mu \mathrm{m}$

Site of tissue development: Pin bones and fins.

Type material: Voucher spores in glycerine-gelatine and histological sections from Barbus barbus, and microscopic photos on spores and histological sections from Iberian barbel were deposited in the parasitological collection of the Zoological Department, Hungarian Natural History Museum, Budapest, Coll. No. HNHM-18219. The 18S rDNA sequences of the Hungarian and Portugal isolate of Myxobolus tauricus were deposited in Genbank under the accession numbers JQ388896 and JQ388897, respectively.
Prevalence of infection: $23 \%$ in young and $13 \%$ in old common barbels and $46 \%$ in Iberian barbel.

Molecular data: The 18S rDNA sequences of 2 Myxobolus tauricus samples from Luciobarbus bocagei (JQ388897) showed 100\% identity. A third sample from Barbus barbus (JQ388896), however, showed $96.7 \%$ similarity to the samples from $L$. bocagei. Genetically, the most similar species to $M$. tauricus was $M$. pavlovskii, sharing 91.2 to $91.3 \%$ sequence similarity over the examined $1331 \mathrm{bp}$ long 18S rDNA fragment. 

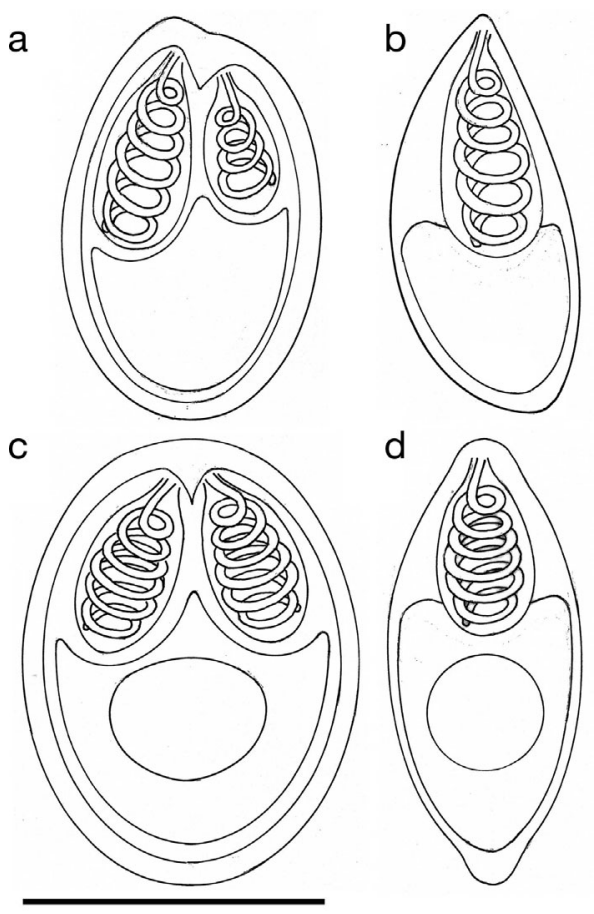

Fig. 10. Schematic drawings of spores of Myxobolus spp. infecting barbels. (a) M. tauricus in frontal view, (b) M. tauricus in sutural view, (c) M. pfeifferi from gill arch in frontal view, (d) $M$. pfeifferi in sutural view. Scale bar $=10 \mu \mathrm{m}$

Histology: In histological sections plasmodia were found in the collagenous connective tissue covering pin bones (Fig. 6). In young fish, they were also found in the dense collagenous tissues between myomers. In Iberian barbels, plasmodia were commonly found in the lumen of the fin rays attached to the collagenous elements (Fig. 8).

Remarks: Morphology and size of the spores collected both in Hungary from the common barbel and in Portugal from the Iberian barbel corresponded to data presented by Miroshnichenko (1979), who described the species from the Crimean barbel Barbus tauricus Kessler. On the basis of myxospore morphology, the species seem to be a common parasite of all of the 3 barbel species. The characteristic shape of the myxospores differentiates the species from all known Myxobolus spp. The genetic difference between the samples from the 2 barbel species (3.3\% over a $1350 \mathrm{bp}$ long fragment of $18 \mathrm{~S}$ rDNA) would suggest that 2 different Myxobolus species infect the fish hosts. However, only one spore sample was examined from common barbel, therefore further study involving additional myxospore isolates could determine whether the observed genetic difference is intra- or interspecific in nature. Furthermore, the fact that $M$. tauricus was originally described from Cri- mean barbel, not from the 2 examined fish species, forces us to rely on morphological data until further studies.

\section{Re-description of Myxobolus pfeifferi Thélohan, 1895}

This species was found only in Iberian barbel in Portugal. Plasmodia of this species were mostly found in the connective tissue septa between muscle cells. A part of plasmodia were located inside the cartilaginous gill arch, where large, roundish plasmodia 160 to $400 \mu \mathrm{m}$ in size were placed in the connective tissue just under the basal part of the gill filaments. In some fish specimens, small plasmodia were also found at the base of gill filaments above the gill arch. Plasmodia contained large-sized ellipsoidal spores.

Spores collected from the gill arch were relatively large, ellipsoidal in frontal view (Figs. 2d \& 10c) and lemon-shaped in sutural view (Figs. $2 d$ inset \& 10d). Spores were $15 \pm 0.51(14.0-15.7) \mu \mathrm{m}$ long $(\mathrm{N}=50)$, $11.2 \pm 0.37(10.5-11.9) \mu \mathrm{m}$ wide $(\mathrm{N}=50)$, and $6.8 \pm$ $0.4(6.2-7.4) \mu \mathrm{m}$ thick $(\mathrm{N}=15)$. Polar capsules were equal in size, pyriform, relatively short, slightly converging anteriorly, and $7.0 \pm 0.85(6.0-9.5) \mu \mathrm{m}$ long $(\mathrm{N}=50)$ and $3.6 \pm 0.23(3.2-3.9) \mu \mathrm{m}$ wide $(\mathrm{N}=50)$. Six polar filament coils were arranged obliquely to the capsule length. A relatively small triangular intercapsular appendix, measuring $1.3 \pm 0.28(1.0-1.7) \mu \mathrm{m}$ $(\mathrm{N}=16)$ was located anteriorly between the capsules. A sutural protrusion formed a circular rim around the spore emerging about 0.7 to $1.0 \mu \mathrm{m}$ over the surface of the spore (Fig. 10d). In sutural view, the thickness of the rim measured about $0.8 \mu \mathrm{m}$. This rim formed a 1 to $1.3 \mu \mathrm{m}$ sutural protrusion at the anterior end and a 0.5 to $0.8 \mu \mathrm{m}$ protrusion at the posterior end. Sutural edge markings were rarely seen in fresh spores. A single bi-nucleated sporoplasm with large, round iodinophilous vacuole was present, while a mucous envelope was not found.

Host: Iberian barbel Luciobarbus bocagei (Steindachner) (Cyprinidae).

Locality: Este River (Portugal).

Site of tissue development: Connective tissues inside gill arches and septa inside the musculature.

Type material: Voucher spores in glycerine-gelatine were deposited in the parasitological collection of the Zoological Department, Hungarian Natural History Museum, Budapest, Coll. No. HNHM-70196. The 18S rDNA sequence of Myxobolus pfeifferi has been deposited in Genbank under the accession number JQ388895. 
Prevalence of infection: $45 \%$.

Histology of infection: Only plasmodia in the gill arch were studied in detail. Plasmodia surrounded with a relatively thin connective tissue were located in the gill arch close to the basis of gill filaments (Fig. 9). Less frequently, some plasmodia were found outside the gill arch at the basis of the gill filaments under the multilayered epithelium of the gill filaments. Inside the muscle, plasmodia inhabited the loose connective tissue of intermuscular septa.

Molecular data: An 1319 bp long 18S rDNA fragment of one sample collected from muscle was obtained. The most closely related species was Myxobolus caudatus with $90.9 \%$ similarity in their 18S rDNA fragment. The DNA sequences of $M$. musculi and $M$. tauricus developing plasmodia in the muscle of barbels, just like $M$. pfeifferi, were similar to the given species but only at $73.8-74.6 \%$ and $86.8-87.8 \%$, respectively.

Remarks: In the muscle, Myxobolus pfeifferi were often found in concomitant infection with $M$. musculi and $M$. tauricus. The 3 species, however, had different tissue locations within muscle. M. musculi plasmodia were always found intracellularly in muscle cells. Plasmodia of $M$. tauricus were in every case attached to the collagenous dense connective tissue covering fish bones, whereas plasmodia of $M$. pfeifferi were found in the loose connective tissue among muscle cells.

Myxobolus pfeifferi is similar in spore morphology to M. cyprinicola Reuss, 1906 from the common carp Cyprinus carpio and M. cycloides ex Leuciscus, a typical parasite of the swimbladder of chub Leuciscus cephalus but they clearly differed at the DNA level (87.6 and 89.2\%, respectively). Due to its frequent basifilamental location, $M$. pfeifferi also resembles $M$. basilamellaris, the parasite of the common carp, but its myxospores are larger and the $18 \mathrm{~S}$ rDNA of the 2 species has only $87.1 \%$ similarity. $M$. pfeifferi spores from the Iberian barbel were larger in size than the spores described by Thélohan (1895). However, to confirm the identification of $M$. pfeifferi, the examination of myxospores collected from common barbel would be required.

\section{Re-description of Myxobolus squamae Keysselitz, 1908}

This species was found in common barbel Barbus barbus in the Danube River. Plasmodia were found on the outer surface of the scales (Fig. 12). Round or amorphous plasmodia on the scales measured up to
$1 \mathrm{~mm}$ in diameter. In some fish specimens, several hundred plasmodia were found, and in a single scale, 1 to 7 plasmodia were counted. Small-sized fish and large specimens were equally infected.

Myxospores in frontal view were ellipsoidal (Figs. 2e \& 11a) and lemon-shaped in sutural view (Figs. 2e insets \& 11b). Spores $11.0 \pm 0.32$ (10.011.4) $\mu \mathrm{m}$ long, $9.1 \pm 0.45(8.4-9.7) \mu \mathrm{m}$ wide, and 6.2 $\pm 0.16(6.0-6.5) \mu \mathrm{m}$ thick. Two polar capsules were elongated and pyriform, equal in size and $5.3 \pm 0.3$ (4.9-5.6) $\mu \mathrm{m}$ long by $3.0 \pm 0.16(2.7-3.2) \mu \mathrm{m}$ wide. Polar filaments coiled densely with 6 turns were arranged perpendicular to the longitudinal axis of capsule. Each spore had a distinct triangular intercapsular appendix of $1.6 \pm 0.13(1.4-1.7) \mu \mathrm{m}$ at the anterior end. Sutural protrusions formed a relatively thin circular rim around the spore emerging about 0.6 to $0.8 \mu \mathrm{m}$ over the surface of the spore. The rim of the suture in sutural view emerged from the spore surface 0.5 to $0.8 \mu \mathrm{m}$ both at the anterior and the posterior ends of the spore. Sutural edge markings were not seen. Sporoplasm nuclei were indiscernible, and a large iodinophilous vacuole was found in the sporoplasm.

Host: Common barbel Barbus barbus (L.).

Localities: Danube River, Hungary.

Site of tissue development: Scales.

Type material: Voucher spores in glycerine jelly and histological sections were deposited in the para-
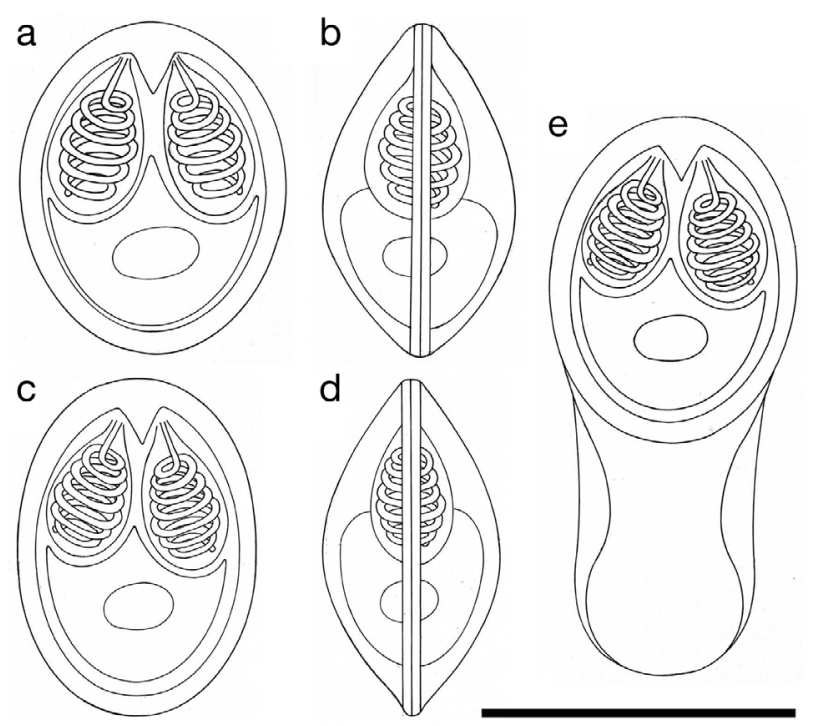

Fig. 11. Schematic drawings of spores of Myxobolus spp. infecting barbels. (a) M. squamae in frontal view, (b) M. squamae in sutural view, (c) $M$. caudatus in frontal view, (d) $M$. caudatus in sutural view, (e) $M$. caudatus spore with mucous attachment. Scale bar $=10 \mu \mathrm{m}$ 
sitological collection of the Zoological Department, Hungarian Natural History Museum, Budapest, Coll. No. HNHM-18220. The 18S rDNA sequence of $M$. squamae was deposited in the GenBank under the accession number JQ388894.

Prevalence of infection: $22 \%$ in young and $13 \%$ in old common barbels.

Molecular data: 18S rDNA sequences of 2 samples of Myxobolus squamae (JQ388894) collected from the scales of 2 common barbel specimens in Hungary showed $100 \%$ similarity. The highest similarity $(92.0 \%)$ was found to be related to the hexactinomyxon-type actinospore (Hexactinomyxon SH-12002, AY162271) described by Hallett et al. (2003). The most closely related species was found to be $M$. caudatus (91.1 to $91.3 \%$ ).

Histology: Roundish, but flattened plasmodia developed in the outer surface of the scales inside the dense connective tissue covering the cartilage (Fig. 13).

Remarks: The species seems to show a tropism to collagenous tissues forming the scales. The morphology and size of Myxobolus squamae spores were very similar to $M$. caudatus Gogebashvili, 1966, but the spores of the former species have no caudal attachments. The $8.7-8.9 \%$ difference in their $18 \mathrm{~S}$ rDNA sequences convincingly supports their differentiation. M. squamae also differs genetically from another 2 'squamaphil' species, M. squamalis (U96495) and the marine species $M$. episquamalis (AY129312) by sharing only $74.3 \%$ and $70.3 \%$ of identical nucleotides over an approx. $1340 \mathrm{bp}$ long DNA fragment, respectively.

\section{Re-description of M. caudatus Gogebashvili, 1966}

Round plasmodia of 1 to $1.5 \mathrm{~mm}$ in diameter containing short ellipsoidal spores with a caudal attachment were found in the fins of small-sized ( 3 to $14 \mathrm{~cm}$ long) common barbels in the Danube River (Fig. 14). Interestingly, the species was not found in barbels $>14 \mathrm{~cm}$. Morphologically identical spores were also observed in the scales and fins of the Iberian barbel.

Myxospores collected from common barbel in Hungary were ellipsoidal in frontal view (Figs. 2f upper inset \& 11c) and lemon-shaped in sutural view (Figs. 2f lower inset \& 11d). Spores were $11.2 \pm 0.32$ (10.6-11.6) $\mu \mathrm{m}$ long, $9.7 \pm 0.19(9.5-11.0) \mu \mathrm{m}$ wide, and $6.2 \pm 0.31(6.0-6.5) \mu \mathrm{m}$ thick. Two polar capsules were elongated and pyriform, equal in size and $4.6 \pm$ 0.27 (4.2-4.8) $\mu \mathrm{m}$ long by $3 \pm 0.32$ (2.5-3.2) $\mu \mathrm{m}$ wide. Polar filaments coiled densely with 6 turns in the polar capsule were located perpendicularly to longitudinal axis of capsule. Spores had a distinct triangular intercapsular appendix of $1.2 \pm 0.29(1.2-1.3) \mu \mathrm{m}$ at the anterior end. Sutural protrusion formed a relatively thin circular rim around the spore emerging about 0.6 to $0.8 \mu \mathrm{m}$ over the surface of the spore. The rim of the suture emerged from the spore surface 0.5 to $0.8 \mu \mathrm{m}$ both at the anterior and the posterior end of the spore. The caudal end of the spores possessed a 15 to $27 \mu \mathrm{m}$ long and 7.5 to $10 \mu \mathrm{m}$ wide curtain-like mucous attachment (Fig. 11e). Less frequently this mucous tail was surrounded by a pale mucous envelope as well. Sutural edge markings were not seen. Sporoplasm nuclei were indiscernible, and a large iodinophilous vacuole was found in the sporoplasm.

Hosts: Common barbel Barbus barbus (L.) (Cyprinidae).

Localities: Danube River, Hungary.

Site of tissue development: Scales and fins.

Type material: Voucher spores in glycerine-jelly from material collected from the Danube River were deposited in the parasitological collection of the Zoological Department, Hungarian Natural History Museum, Budapest, Coll. No. HNHM-18221. The 18S rDNA sequence of $M$. caudatus was deposited in the GenBank under the accession number JQ388889.

Prevalence of infection: $6 \%$ in 3 to $8 \mathrm{~cm}$ long juvenile barbels ( 3 mo old).

Molecular data: The 2 samples of Myxobolus caudatus possessed $99.9 \%$ similarity over a 1313 bp long fragment of $18 \mathrm{~S}$ rDNA. Of the other myxozoan species from barbel, the 18S rDNA sequence of M. squamae showed the highest similarity (91.1 to $91.3 \%$ ). The similarity detected between $M$. caudatus and a hexactinomyxon-type actinospore (Hexactinomyxon SH-2006, DQ473517) described from the oligochaete host Psammoryctides albicola in Syria by Székely et al. (2007) was $96.0 \%$.

Histology: Roundish or ellipsoid plasmodia on the fins developed in the connective tissue between 2 fin rays, but they attached to the outer surface of the cartilaginous fin rays (Fig. 14). Less frequently, plasmodia were also found in the scales at a similar location as Myxobolus squamae.

Remarks: Because of the wide curtain-like mucous attachment at the caudal end of the spores, Landsberg \& Lom (1991) classified Myxobolus caudatus into the genus Unicauda Davis, 1924. However, due to the typical structure of the spores, the uncertain visibility of the caudal attachment, and the genetic relation to Myxobolus spp., we find it justified to include this species as a member of the genus Myxobolus. 

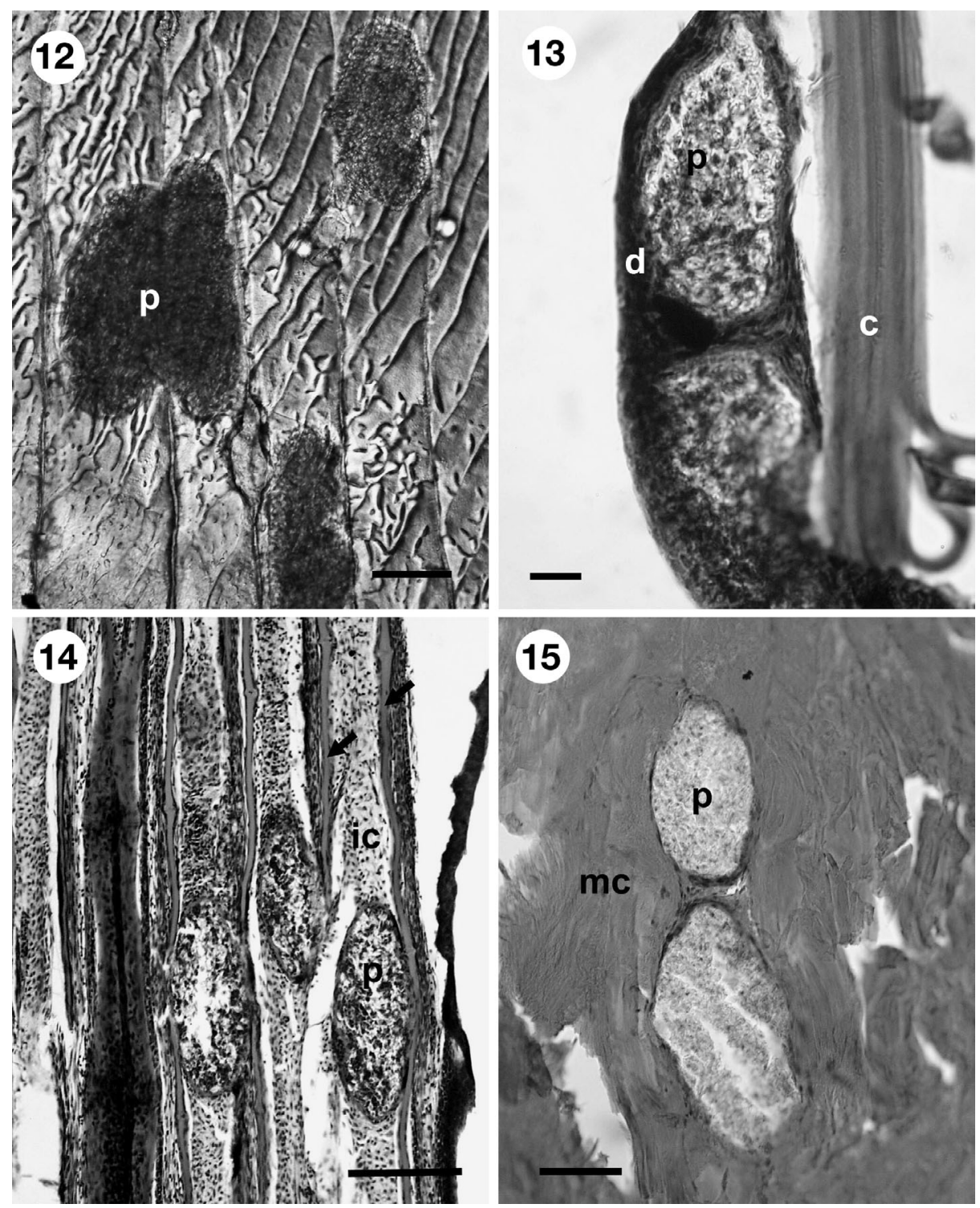

Figs. 12 to 15. Plasmodia (p) of Myxobolus spp. infecting barbel. Fig. 12. M. squamae on the outer side of a barbel's scale. Fresh mounts. Scale bar $=50 \mu \mathrm{m}$. Fig. 13. M. squamae attaching to the outer surface of the cartilage (c) and covered by a thin layer of the dermis (d). Histological section. H \& E. Scale bar $=100 \mu \mathrm{m}$. Fig. 14. M. caudatus attaching to the (arrow) cartilaginous finrays in the inter-rays connective tissue (ic). Histological section. $\overline{\mathrm{H} \& \mathrm{E} .}$ Scale bar $=50 \mu \mathrm{m}$. Fig. 15. M. musculi inside muscle cell (mc). Histological section. H \& E. Scale bar $=20 \mu \mathrm{m}$

The species seems to show a tropism to collagenous tissues of the scales and the fins but actually it develops in the collagenous dense connective tissue forming the cartilage. The location of the species resembles that of Myxobolus tauricus, but the location of plasmodia differs in the fins. $M$. tauricus always seems to be located inside the cavity of the fin rays, whereas the plasmodia of $M$. caudatus develop outside the fin rays. The morphology and size of spores of $M$. caudatus resembles $M$. squamae very much, but the spores of the latter species have no caudal attachments and their 18S rDNA share identical nucleotides in 91.1-91.3\% only.

The size and morphology of Myxobolus caudatus spores collected in the course of the present study in Danube barbel correspond to the spores of $M$. cutanei described by Alvarez-Pellitero \& GonzalezLanza (1985) from the Esla River, and the ones found by us in Iberian barbel from the Este River. However, the 4 to $4.2 \%$ difference of $18 \mathrm{~S}$ rDNA sequences between samples from the 2 barbel species gives us a reason to reassess $M$. cutanei that 
was regarded as a synonym of $M$. caudatus for a long time.

\section{Myxobolus cutanei Álvarez-Pellitero \& González-Lanza, 1985}

This species was found in Iberian barbel. Six of the 22 fish examined (27\%) were infected with small, round plasmodia in the scales and fins. The size and shape of spores (Fig. 2f, Table 2) corresponded to data given by Álvarez-Pellitero \& González-Lanza (1985) and to those measured for Myxobolus caudatus infection of the common barbel in the present study. The 18S rDNA sequence of 2 samples of $M$. cutanei (having 99.8\% similarity) differed in 4.0$4.2 \%$ from the DNA sequences of $M$. caudatus. The 18S rDNA sequence of $M$. cutanei was deposited in GenBank under the accession number JQ388890.

\section{Myxobolus musculi Keysselitz, 1908}

This species infected all large-sized common barbel and Iberian barbel specimens but was rare in fishes under $12 \mathrm{~cm}$ in length. Spores developed in intramuscular plasmodia (Fig. 15). The infection prevalence was $44 \%$ in common barbel, and $50 \%$ in Iberian barbel. Spores collected from the common barbel and the Iberian barbel corresponded in shape and size.

Three samples from Iberian barbel (GenBank Accession Nos. JQ388891, JQ388892, JQ388893) had only 97.0-97.2\% similarity over a 1912 bp long fragment of $18 \mathrm{~S}$ rDNA. The DNA sequences of the 3 myxospore isolates differed by $2.4-2.7 \%$ from that of Myxobolus musculi (AF380141) studied previously. Interestingly, the genetic variations among the samples were located only on the variable regions of the gene. $M$. musculi is also closely related to $M$. cyprini (AF380140) and M. pseudodispar ex Rutilus (AF380145) (95.8-96.0 and 95.5$96.2 \%$ similarity over a 1484 bp long 18S rDNA fragment, respectively).

\section{DISCUSSION}

The comparative study involving morphology, histology and phylogeny showed that the myxosporean fauna of common and Iberian barbel species are rather similar. On the basis of myxospore morphology alone, 5 of the 8 examined Myxobolus species occurred in both fishes. Besides the muscle-dwelling M. musculi, the gill parasite $M$. branchialis seemed to be the most common Myxobolus species of barbels. This species formed small plasmodia in the capillary network of the gill lamellae, commonly infected the gills of small- and large-sized fish, and was frequently found both in common barbel in Hungary and in Iberian barbel in Portugal. Its small-sized spores without iodinophilous vacuoles in the sporoplasms were hardly distinguishable from spores of $M$. branchilateralis sp. n.. However the latter species formed large, distinct plasmodia at the base of the filaments and the 18S rDNA sequences of its spores also differed from $M$. branchialis. $M$. branchialis infection in the gills was probably the species which was described in Iberian barbel by Álvarez-Pellitero \& González-Lanza (1985) in Spain, who concluded their species was the same as M. lobatus Dogiel, 1934, a species re-named by Landsberg \& Lom (1991) to M. valdogieli. The shape and size of $M$. valdogieli and $M$. branchialis correspond to each other, but according to the original description, M. valdogieli (i.e. M. lobatus) also has an iodinophilous vacuole in the sporoplasm of the spores. The presence or absence of an iodinophilous vacuole in the spore is an important characteristic, but in the cases of less thorough examination, it could easily be overlooked. In our study, iodinophilous vacuoles were found neither in the Hungarian nor in the Iberian samples, therefore the validity of M. valdogieli is questionable. Álvarez-Pellitero \& González-Lanza (1985) have not reported the presence of a iodinophilous vacuole in the examined spores; therefore it is likely that they also dealt with a $M$. branchialis infection.

In barbels caught in Hungary, the muscle was mostly infected by 1 , and less frequently by 2 , Myxobolus species. In small barbels, $M$. tauricus was the most common Myxobolus species, whereas in large-sized fish, the infection with $M$. musculi dominated and $M$. tauricus occurred very rarely. In Iberian barbel, 3 Myxobolus spp. (M. musculi, M. tauricus and $M$. pfeifferi) were frequently present. Although M. musculi plasmodia affected muscle cells, $M$. tauricus plasmodia were found in fish bones and $M$. pfeifferi plasmodia located in the intermuscular septa, which made the precise separation of the plasmodia of the 3 species rather difficult- Therefore, obtaining pure material for molecular studies was rather problematic. For this reason, several myxospore isolates that were determined to contain spores of a contaminating species had to be excluded from the study (data not shown). 
Special attention was paid to Myxobolus pfeifferi due to its pathogenicity. It causes boil disease, an illness making large nodules in the muscle and distortions of the fish body (Schäperclaus 1954). This species is one of the best known Myxobolus species. Therefore it was a surprise that $M$. pfeifferi has not been detected in Hungary up to this time. Although M. pfeifferi was described by Thélohan (1895) as a parasite infecting connective tissue in different parts of the barbel's body, the species has been long regarded to be a parasite of the musculature. The present study demonstrates that, contrary to the intracellular M. musculi species studied by Molnár et al. (2002), M. pfeifferi do not infect muscle cells, and boils caused in the muscle seem to develop in the intermuscular connective tissue elements. It is rather peculiar that the species frequently develops in a basifilamental position in the gill arch. Donec \& Shulman (1984) mentioned M. pfeifferi from different barbel species, but Longshaw et al. (2005) recorded it in other cyprinids than the barbel. The shape of the spores found by us in Iberian barbel resemble the original drawings of Thélohan (1895) but somewhat differ from spores depicted by Keysselitz (1908) and Donec \& Shulman (1984). The species was probably found by Álvarez-Pellitero \& González-Lanza (1985) in Iberian barbel, but these authors identified it as $M$. muelleri Bütschli, 1982. We share Donec \& Shulman's (1984) opinion that M. pfeifferi could parasitize several barbel species, but we suggest that $M$. pfeifferi spores described by Longshaw et al. (2005) from cyprinid fishes other than barbels likely represent another Myxobolus species.

Myxobolus tauricus, described originally from the Crimean barbel (Barbus tauricus), seems to be common in B. barbus and Luciobarbus bocagei as well. Surprisingly, the species, which is known to infect the intramuscular fish bones in common barbel only, could also commonly infect the fin rays of Iberian barbel. Álvarez-Pellitero et al. (1982), who first described $M$. tauricus infection in the Iberian Peninsula, also found this parasite in different fish tissues.

Myxobolus caudatus was also commonly found both in Hungary and Portugal on the fins of barbels. Among the species observed in this study, both $M$. tauricus and $M$. caudatus had a certain tropism to collagenous tissues, and they caused fin infections. There was, however, a difference between the infections caused by the 2 species. Plasmodia of $M$. tauricus developed inside the cavity of fin rays, while plasmodia of $M$. caudatus attached to the outer surface of the fin rays. Apart from the caudal extension of the spores, $M$. caudatus resembles $M$. squamae, the parasite of the scales. Due to the great similarity in morphology and location of $M$. squamae and $M$. caudatus spores, prior to molecular examinations, we agreed with the synonymy of the 2 species. However, the genetic characterization showing only $91 \%$ similarity in the 18S rDNA sequences of spore samples with or without caudal extensions proved the validity of the 2 closely related Myxobolus species.

Donec \& Shulman (1984) stated that plasmodia of Myxobolus squamae developed in the internal side of the scales, but our histological preparations show that the plasmodia develop on the outer surface of the scales. For a long time, identification of a species and description of a new species relied on myxospore morphology only, however it was proven that the examination of additional characters like tissue tropism and DNA sequence data in correlation with spore morphology is required for the precise identification of myxozoan species (Andree et al. 1999, Eszterbauer 2004, Ferguson et al. 2008). With the use of molecular methods, the identification of morphologically similar spores became easier, but at the same time new problems emerged. Morphological data and observations made on tissue tropism suggests that the same Myxobolus species infect the 2 barbel species, but differences in 18S rDNA sequences obtained from spores morphologically corresponding to $M$. caudatus suggests that different Myxobolus species infect the 2 barbel species. Comparing the 18S rDNA sequences of $M$. caudatus isolates from common barbel and Iberian barbel, the genetic differences are larger (4 to $4.2 \%$ ) than $1 \%$, which is a suggested limitation of the intraspecific variation within species of the histozoic freshwater myxozoans including the members of the genus Myxobolus. This limitation occurs for the majority of species studied hitherto (authors' pers. obs.). This result suggests that the Iberian parasite represents another species that is genetically different from M. caudatus, but has the same spore morphology, tissue tropism and a closely related fish host. This species is M. cutanei Álvarez-Pellitero \& GonzálezLanza, 1985, that was thought as a synonym of $M$. caudatus for a long time, but due to our findings, it should be reassessed. In a similar way, differences found in sequences of $M$. tauricus of Hungarian and Portuguese samples suggest the possibility of the existence of 2 independent species. However to prove this theory, the examination of further samples of $M$. tauricus spores from common barbel is required. Until further detailed examination, we regard the morphologically identical Myxobolus tauricus-like isolates found in the 2 barbel species as representative of a single species. 
Unfortunately the original purpose of this study, namely to compare the morphologically identical species infecting related barbel species from 2 geographical regions, could not be accomplished entirely mainly due to PCR inhibition. The high level of similarity in shape and size of the myxospores, in addition to the similar location in the fish body, suggest the common origin of the examined species from both habitats. The differences in 18S rDNA found for Myxobolus caudatus, M. tauricus and M. musculi, the 3 species studied in both habitats, suggest that we have to consider species diversification of myxosporean parasites, similarly to the host species, which according to a new classification, belong to 2 genera (Barbus and Luciobarbus) of barbels (Froese \& Pauly 2012). For M. musculi, the problem is more complicated. Samples obtained from Iberian barbel differed from the one available in GenBank from common barbel as they were only 97.3 to $97.6 \%$ similar, but the 3 isolates from Iberian barbel also differed from each other by about the same level. In this case, we cannot give a definite explanation to the differences. It can be seen that the interspecific variability of the species is similar to that of $M$. pseudodispar (Molnár et al. 2002), and further studies on these muscle-infecting Myxobolus species is needed to answer whether the genetic difference is intraspecific in nature or whether these species have to be treated as cryptic species. As the phylogeny of barbels resulted in forming different barbel species in the Iberian Peninsula and in the continental part of Europe (Doadrio et al. 2002, Froese \& Pauly 2012), it is likely that parasites infecting these fishes also followed a way of species diversification due to co-evolution. Based on our present study we cannot exclude that Myxobolus species infecting common barbel and Iberian barbel that have similar organ and tissue affinity might have developed into different species. The approx. $3 \%$ difference in the 18S rDNA of $M$. musculi and $M$. tauricus isolates suggests that although the Myxobolus fauna of the 2 fish species are morphologically similar, they are genetically segregated myxosporea species, which could be regarded to be independent after more thorough examinations involving further samples.

Acknowledgements. The study was supported by the Hungarian Scientific Research Fund (OTKA, projects no. K71837 and K75873), by the Foundation for Science and Technology (Portugal) and by the Hungarian Science and Technology Foundation, in the frame of the Hungarian-Portuguese Intergovernmental S\&T Cooperation Programme. The authors thank G. Pataki for preparing drawings and histological slides.

\section{LITERATURE CITED}

Álvarez-Pellitero MP, Pereira-Bueno JM, González-Lanza C (1982) On the occurrence of Myxobolus tauricus Miroshnichenko, 1979 in Barbus barbus bocagei from Leon (Duero Basin, NW Spain). Bull Eur Assoc Fish Pathol 2: $1-3$

Álvarez-Pellitero MP, González-Lanza C (1985) Studies on Myxobolus spp. of Barbus barbus bocagei from the river Esla (León, NW Spain). Angew Parasitol 26:3-12

Andree KB, Székely C, Molnár K, Gresoviac SJ, Hedrick RP (1999) Relationships among members of the genus Myxobolus (Myxozoa: Bilvalvidae) based on small subunit ribosomal DNA sequences. J Parasitol 85:68-74

> Corpet F (1988) Multiple sequence alignment with hierarchical clustering. Nucleic Acids Res 16:10881-10890

> Doadrio I, Carmona JA, Machordom A (2002) Haplotype diversity and phylogenetic relationships among the Iberian barbels (Barbus, Cyprinidae) reveal two evolutionary lineages. J Hered 93:140-147

Donec ZS, Shulman SS (1984) Knidosporidii (Cnidosporidia). In: Bauer ON (ed) Key to the parasites of freshwater fishes of the USSR, Vol 1. Nauka, Leningrad, p 88-251 (in Russian)

> Eiras JC, Molnár K, Lu YS (2005) Synopsis of the species of Myxobolus Bütschli, 1882 (Myxozoa: Myxosporea: Myxobolidae). Syst Parasitol 61:1-46

> Eszterbauer E (2004) Genetic relationship among gill-infecting Myxobolus species (Myxosporea) of cyprinids: molecular evidence of importance of tissue-specificity. Dis Aquat Org 58:35-40

Eszterbauer E, Székely C (2004) Molecular phylogeny of the kidney-parasitic Sphaerospora renicola from common carp (Cyprinus carpio) and Sphaerospora sp. from goldfish (Carassius auratus auratus). Acta Vet Hung 52: 469-478

Ferguson JA, Atkinson SD, Whipps CM, Kent ML (2008) Molecular and morphological analysis of Myxobolus spp. of salmonid fishes with the description of a new Myxobolus species. J Parasitol 94:1322-1334

Froese R, Pauly D (2012) FishBase. Accessed Aug 2012. www.fishbase.org

Hall TA (1999) BioEdit: a user-friendly biological sequence alignment editor and analysis program for Windows 95/98/NT. Nucleic Acids Symp Ser 41:95-98

Hallett SL, Diamant A (2001) Ultrastructure and small-subunit ribosomal DNA sequence of Henneguya lesteri n. sp. (Myxosporea), a parasite of sand whiting Sillago analis (Sillaginidae) from the coast of Queensland, Australia. Dis Aquat Org 46:197-212

Hallett SL, Atkinson SD, Schöl H, El-Matbouli M (2003) Characterisation of two novel types of hexactinomyxon spores (Myxozoa) with subsidiary protrusions on their caudal processes. Dis Aquat Org 55:45-57

> Hillis DM, Dixon MT (1991) Ribosomal DNA: molecular evolution and phylogenetic inference. Q Rev Biol 66:411-453

> Huelsenbeck JP, Ronquist F (2001) MRBAYES: Bayesian inference of phylogenetic trees. Bioinformatics 17:754-755

Keysselitz G (1908) Über durch Sporozoen (Myxosporidien) hervorgerufene pathologische Veränderungen. Verh Ges Dtsch Naturforsch Ärzte 2:542-543

Landsberg JH, Lom J (1991) Taxonomy of the genera of the Myxobolus/Myxosoma group (Myxobolidae: Myxosporea), current listing of species and revision of synonyms. Syst Parasitol 18:165-186 
Lom J, Arthur JR (1989) A guideline for the preparation of species descriptions in Myxosporea. J Fish Dis 12: 151-156

Longshaw M, Frear PA, Feist SW (2005) Descriptions, development and pathogenicity of myxozoan (Myxozoa: Myxosporea) parasites of juvenile cyprinids (Pisces: Cyprinidae). J Fish Dis 28:489-508

Milne I, Lindner D, Bayer M, Husmeier D, McGuire G, Marshall DF, Wright F (2009) TOPALi v2: a rich graphical interface for evolutionary analyses of multiple alignments on HPC clusters and multi-core desktops. Bioinformatics 25:126-127

Miroshnichenko AI (1979) Myxobolus tauricus sp. n., a new species of myxosporidians (Cnidosporidia: Myxosporidia) from the Crimean barbel. Parazitologiia 13:436-437 (in Russian)

Molnár K, Eszterbauer E, Székely C, Dán Á, Harrach B (2002) Morphological and molecular biological studies

Editorial responsibility: Gunnar Bratbak,

Bergen, Norway on intramuscular Myxobolus spp. of cyprinid fish. J Fish Dis 25:643-652

Schäperclaus W (1954) Fischkrankheiten. Akademie-Verlag, Berlin

Staden R (1996) The Staden sequence analysis package. Mol Biotechnol 5:233-241

Székely C, Hallett SL, Al-Samman A, Dayoub A (2007) First description of myxozoans from Syria: novel records of hexactinomyxon, triactinomyxon and endocapsa actinospore types. Dis Aquat Org 74:127-137

Thélohan P (1895) Recherches sur les myxosporidies. Bull Sci Fr Belg 26:100-394

Whipps CM, Adlard RD, Bryant MS, Lester RJG, Findlay V, Kent ML (2003) First report of three Kudoa species from eastern Australia: Kudoa thyrsites from mahi mahi (Coryphaena hippurus), Kudoa amamiensis and Kudoa minithyrsites n. sp. from sweeper (Pempheris ypsilychnus). J Eukaryot Microbiol 50:215-219

Submitted: January 16, 2012; Accepted: March 15, 2012

Proofs received from author(s): September 4, 2012 